\title{
Effects of seagrass landscape structure, structural complexity and hydrodynamic regime on macro- faunal densities in North Carolina seagrass beds
}

\author{
Kevin A. Hovel*, Mark S. Fonseca, D. L. Myer, W. J. Kenworthy, P. E. Whitfield \\ Center for Coastal Fisheries and Habitat Research, National Oceanic and Atmospheric Administration/National Ocean Service, \\ 101 Pivers Island Road, Beaufort, North Carolina 28516, USA
}

\begin{abstract}
Seagrass habitats exhibit high structural variability at local ( $<1$ to $10 \mathrm{~s}$ of $\mathrm{m}$ ) and landscape (100 to 1000s of m) scales, which is closely linked with physical setting. In this study, we conducted 2 spring and 2 fall field surveys in 1991 and 1992 over a $25 \mathrm{~km}$ long portion of Core and Back Sounds, North Carolina, USA, to relate macrofaunal abundance to measures of seagrass landscape structure and associated ecological variables. Independent variables included seagrass bed structure (percent cover and total linear edge), local-scale ecological attributes (shoot density, shoot biomass, percent sediment organic matter) and elements of physical setting (water depth and energy regime as estimated by a relative wave exposure index [REI]). Seagrass beds were composed of eelgrass (Zostera marina: fall/spring-dominant), shoalgrass (Halodule wrightii: summer-dominant), some widgeongrass (Ruppia maritima) and minor amounts of macroalgae. Seagrass coverage ranged from highly patchy (13\% cover) dune-like beds to continuous (100\% cover) low-relief beds within 18 replicate $50 \times 50 \mathrm{~m}$ plots. Twelve species (8 decapods and 4 fishes) made up $95 \%$ or more of the catch, and densities of nearly all varied significantly between seasons and years. Multiple regression analysis indicated that relationships between faunal densities and environmental variables varied greatly between species and between collection periods. In addition, species-specific correlations between faunal density and environmental variables generally were not consistent among the 4 collection periods. REI and seagrass shoot biomass appeared to have the greatest influence on species' densities, with REI having more influence on densities in 1991 and shoot biomass having more influence on densities in 1992. Seagrass percent cover and total linear edge explained little of the variation in species' densities. Only blue crab Callinectes sapidus density was (positively) correlated with seagrass percent cover in the spring of 1992. In principal components analyses, species groupings were inconsistent between collection periods, though grouping by relative abundance was evident in some collection periods. There was little separation between crustaceans and fishes in principal component space, but sites of high faunal abundance were distinct from sites of low faunal abundance. Sites with consistently high faunal abundance generally were found in western Core and Back Sounds, whereas sites with consistently low faunal abundance were found in eastern Core Sound, suggesting that processes operating at larger than landscape spatial scales (e.g. larval delivery by currents) may influence faunal community patterns in these seagrass landscapes. The influence of a variety of covarying factors on fauna operating over a range of spatial scales highlights fundamental differences in the relationship between landscape structure and animal abundance in seagrass versus terrestrial habitats.
\end{abstract}

KEY WORDS: Abundance - Epifauna $\cdot$ Habitat fragmentation $\cdot$ Landscape ecology $\cdot$ Relative wave exposure index $\cdot$ Seagrass $\cdot$ Structural complexity

Resale or republication not permitted without written consent of the publisher

\section{INTRODUCTION}

${ }^{*}$ Present address: Department of Biology, San Diego State University, 5500 Campanile Drive, San Diego, California 92182, USA. Email: hovel@sciences.sdsu.edu
The abundance and distribution of organisms in space and time often are intimately linked to habitat 
structure at a variety of spatial scales (Bell et al. 1991, Real \& Levin 1991, Elliot et al. 1998). The influence of structure on species persistence at the landscape scale is receiving increasing attention as human activities continue to drastically alter the configuration of natural habitats. Generally, the conversion of continuous habitat to small isolated patches (i.e. habitat fragmentation) decreases the reproductive output (Temple \& Cary 1988, Robinson et al. 1995; but see Tewksbury et al. 1998), movement (van Appeldoorn et al. 1992), survival (Gates \& Gysel 1978, Brittingham \& Temple 1983, Wilcove 1985, Small \& Hunter 1988, Andrén 1992, Robinson et al. 1995) and population size (Brittingham \& Temple 1983) of many species in terrestrial landscapes.

Seagrasses, which harbor dense and diverse faunal assemblages in coastal shallows worldwide (Petersen 1918, Orth 1992), often form extensive, continuous meadows in areas of low hydrodynamic activity but can be maintained as small, isolated patches by strong waves and currents (Fonseca \& Bell 1998) and bottomfeeding and burrowing animals (Townsend \& Fonseca 1998, author's pers. obs.). Seagrasses also are fragmented by propeller scarring and vessel groundings (Sargent et al. 1995). Therefore, as in fragmented forests, variation in seagrass habitat structure at the landscape scale (100s to 1000 s of $\mathrm{m}$ ) may influence processes (e.g. predation) that shape faunal abundance and structure communities (Robbins \& Bell 1994, Frost et al. 1999, Hovel \& Lipcius 2001). At the local scale $(<1$ to 10 s of $\mathrm{m})$, elements of seagrass structural complexity such as shoot density, shoot biomass or leaf surface area also have been invoked as important determinants of faunal abundance (see reviews by Orth et al. 1984, Heck \& Crowder 1991, Orth 1992). Faunal abundance is enhanced in areas of high shoot density or biomass due to reduced predator foraging efficiency and enhanced living space and food (Heck \& Orth 1980, Orth \& van Montfrans 1982, Bell \& Westoby 1986, Orth 1992, Perkins-Visser et al. 1996). Structurally complex seagrass beds also may be actively selected by fauna (Bell \& Westoby 1986, Orth 1992, Worthington et al. 1992).

Both local- and landscape-scale habitat structure therefore may shape faunal communities in seagrass habitats. However, the influence of landscape-scale habitat structure on the survival and abundance of organisms in seagrass and other subtidal habitats has received little attention (but see Irlandi 1994, 1997, Irlandi et al. 1995, Frost et al. 1999, Hovel \& Lipcius 2001), and rarely have the effects of habitat structure on faunal abundance at the local and landscape scale been compared (but see Turner et al. 1999). The singular effects of local-scale habitat structure, landscape-scale structure and hydrodynamic activity on fauna are difficult to determine because they typically covary; for instance, strong waves may fragment seagrass, and small seagrass patches may be less structurally complex than larger patches (e.g. Irlandi 1997). Our objective in this study was to compare the influence of landscape-scale habitat structure on seagrass faunal densities to the influence of local-scale structure and hydrodynamic activity by statistically eliminating confounding between variables within each of these categories.

In 1991 and 1992 a large-scale survey of North Carolina seagrass habitat was initiated with the goal of linking seagrass habitat characteristics (e.g. landscape structure and local-scale structural complexity) to physical disturbance across a gradient of hydrodynamic regimes (see Bell et al. 1994, Murphey \& Fonseca 1995, Fonseca \& Bell 1998, Townsend \& Fonseca 1998). Here, we use data on animal abundance, seagrass landscape structure, local-scale structural complexity and water motion from this survey to answer the following questions: (1) How do seagrass fragmentation, seagrass structural complexity and hydrodynamic regime jointly influence the abundance of common seagrass bed macroepibenthic fauna? (2) Are effects of these variables on faunal abundance similar between seasons (spring and fall) and years (1991 and 1992)? (3) Do different species groups (e.g. decapods versus fishes) respond differently to habitat and hydrodynamic characteristics? (4) How can faunal species and habitats be grouped on the basis of faunal abundance, and are these associations similar between seasons and years?

\section{MATERIALS AND METHODS}

This study was conducted in the seagrass meadows of Core and Back sounds, Carteret County, North Carolina, USA $\left(34^{\circ} 40^{\prime}\right.$ to $34^{\circ} 50^{\prime} \mathrm{N}, 76^{\circ} 20^{\prime}$ to $76^{\circ} 40^{\prime} \mathrm{W}$; ca. $25 \mathrm{~km}$ linear distance; Fig. 1). Seagrass meadows in Core and Back sounds are composed of Zostera marina (eelgrass), Halodule wrightii (shoalgrass) and Ruppia maritima (widgeongrass). Seagrass mapping, current and water depth measurement, seagrass sampling and faunal sampling all were conducted in May and November 1991 and May to June and November 1992. These spring and fall survey periods coincided with peaks in biomass for the 2 dominant seagrass species (Z. marina in May to June and $H$. wrightii in November).

Selection of study sites, seagrass mapping techniques, and methods for measuring seagrass structural complexity (shoot density and above-ground biomass per $\mathrm{m}^{2}$ ) and hydrodynamic characteristics (water depth and tidal current speed) are detailed in Fonseca \& Bell (1998). Briefly, eighteen $50 \times 50 \mathrm{~m}$ study sites were 
chosen after examining aerial photographs of seagrass habitat to represent a broad range of seagrass coverage. Seagrass coverage was mapped in each site by examining each of the 2500 contiguous $1 \times 1 \mathrm{~m}$ quadrats for the presence or absence of seagrass. Quadrats were situated at the intersection of $\mathrm{m}^{2}$ grids, which were located by systematically moving a $50 \mathrm{~m}$ lead line across each site. From the mapping data we calculated 2 measures of landscape structure for each site: seagrass percent cover (fraction of quadrats occupied by seagrass $\times 100$ ) and total linear edge (number of vegetated quadrat edges adjacent to unvegetated edges). Seagrass shoot density and above-ground biomass were measured from three $25 \mathrm{~cm}$ diameter seagrass cores taken randomly in each of three $1 \mathrm{~m}^{2}$ quadrats randomly placed in seagrass at each site. Seagrass shoots were counted to obtain an estimate of shoot density and then were dried to a constant weight at $80^{\circ} \mathrm{C}$ to estimate above-ground biomass per $\mathrm{m}^{2}$. Grand means then were calculated for each site by averaging core values in each quadrat and then averaging quadrats. Three randomly placed $3 \mathrm{~cm}$ diameter sediment cores also were taken in seagrass at each site and, after drying at $105^{\circ} \mathrm{C}$, were combusted at $500^{\circ} \mathrm{C}$ to determine percent organic content. Water depth was measured at every $1 \mathrm{~m}$ grid point along every third transect in the mapping survey, and then averaged for each site after correction for tidal height change and expressed as elevation relative to mean sea level.

We used a relative wave exposure index (REI) to estimate physical setting for each site (see Murphey \& Fonseca 1995, Fonseca \& Bell 1998 for details). Wind speed and frequency data and effective fetch measurements were used in the following equation:

$$
\text { REI }=\sum_{i=1}^{8}\left(V_{i} \times P_{i} \times F_{i}\right)
$$

where $i$ is the $i$ th compass heading (1 to 8 [N, NE, E, etc.] in $45^{\circ}$ increments), $V$ is the average monthly maximum wind speed in $\mathrm{m} \mathrm{s}^{-1}, P$ is the percent frequency with which wind occurred from the ith direction, and $F$ is the effective fetch $(\mathrm{m})$. Though tidal current speed also was measured, we did not use it in analyses because it was strongly correlated with REI (Fonseca \& Bell 1998).

We used $1 \mathrm{~m}^{2}$ throw-traps to determine macrofaunal abundance at each site (Bell et al. 1994). During each collection period, $1 \mathrm{~m}^{2}$ throw-traps were set at 3 randomly selected seagrass-covered locations within each $50 \times 50 \mathrm{~m}$ site ( 3 throw-traps per site $\times 18$ sites per collection period $\times 4$ collection periods $=216$ total throw-trap samples). A throw-trap consisted of a $1.0 \times 1.0 \mathrm{~m}$ sheet metal frame (height $23 \mathrm{~cm})$ attached to a $1.5 \mathrm{~m}$ tall mesh collar $(1.6 \mathrm{~mm}$ mesh), which was riveted around the top of the metal frame. A square segment of $5.8 \mathrm{~cm}$ diameter polyvinyl chloride (PVC) pipe was attached to the top of the mesh collar for flotation. Once a throw-trap was in place, environmental data (salinity, current velocity, water and air temperatures, and water depth at the center of each throw-trap), seagrass coverage estimates, and sediment and seagrass core samples were taken from within the trap, and macrofauna then were removed. During 1991, macrofauna were collected using a venturi suction sampler that pumped $\sim 120 \mathrm{l} \mathrm{min}^{-1}$ through a $16 \mathrm{~cm}$ hose. Each throw-trap was systematically suctioned for $3 \mathrm{~min}$ and material was collected in a $1.6 \mathrm{~mm}$ mesh catch sock. Once suctioned, the throw-trap was dip-netted $(0.46 \times 0.36 \mathrm{~m}$ net with $1.6 \mathrm{~mm}$ mesh $) 10$ times and seined $(1.5 \times 1.0 \mathrm{~m}$ seine with $1.6 \mathrm{~mm}$ mesh) 3 times to capture any remaining fauna, especially larger fish that avoided the suction sampler. If the water depth within the throw-trap was $<0.25 \mathrm{~m}$, a venturi effect could not be achieved and the suction sampler was not used. Instead, the entire throw-trap volume was dip netted 15 times and then seined 3 times. Because of the excessive amount of labor needed to process suction samples (6 to $12 \mathrm{~h} \mathrm{sample}{ }^{-1}$ ) the suction sampling method was discontinued in 1992 in favor of a set menu of 15 dip net

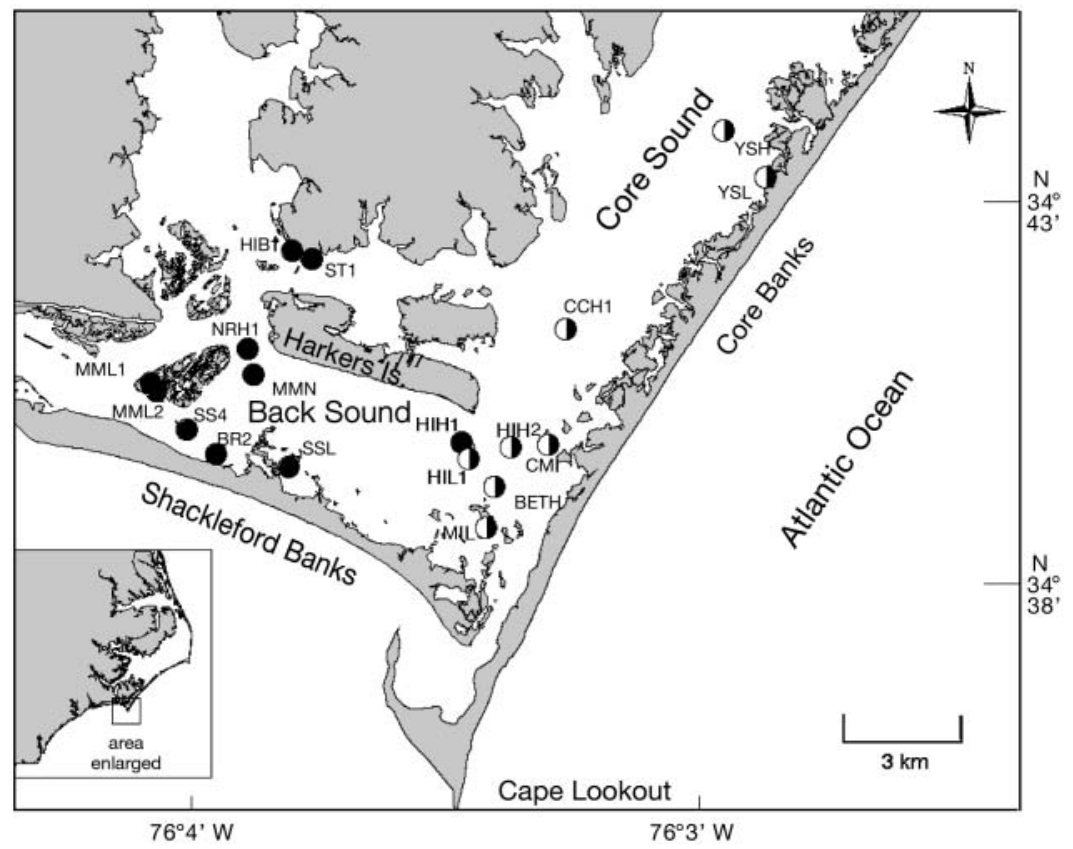

Fig. 1. Location of the 18 sites surveyed in spring and fall 1991 and 1992 in Core and Back sounds, North Carolina, USA (modified from Townsend \& Fonseca 1998). Faunal abundance: high, low 
and 3 seine passes. Capture efficiency was estimated to be $\sim 95 \%$ based on a Monte Carlo simulation (not shown) of the number of animals caught per dip net until 3 successive passes yielded no catch (30 throwtraps fished to catch extinction used in the simulation). All material and fauna collected within the catch sock, dip nets and seines were immediately placed in storage containers with $95 \%$ ethyl alcohol for processing at the laboratory.

Laboratory sample processing consisted of sorting through the collected material for all fish and decapod crustaceans, which were identified to species, enumerated and measured to the nearest $0.1 \mathrm{~mm}$ (standard length for fishes, carapace length for shrimp and spineto-spine carapace width for crabs).

Data analysis. Faunal densities and environmental variables: We used a 2-way, fixed-factor ANOVA for each species to test for differences in faunal densities between spring and fall and between 1991 and 1992 . Two-way, fixed-factor ANOVAs also were used to test for differences in environmental variables (REI, depth, percent seagrass cover, total linear edge, shoot biomass, shoot density and percent organic matter) between seasons and years. We used Cochran's test to test for heterogeneity of variances for all ANOVAs and used $\ln (x+1)$ transformations to homogenize data when necessary to meet the assumptions of ANOVA (Underwood 1997). Student-Newman-Keuls (SNK) multiple comparisons were used to test which means differed at $\mathrm{p}<0.05$ (Underwood 1997).

Faunal-environmental correlations: We used stepwise multiple linear regression (1 for each collection period: PROC REG in PC SAS 8.01), with a 'P-to-enter' value of 0.05 and a 'P-to-remove' value of 0.10 (Sokal $\&$ Rohlf 1981) to test for correlations between macrofaunal densities and environmental variables (Table 1). We also regressed the total abundance of fauna at each site and the total number of species at each site on environmental variables. Though data on all environmental variables were collected for each site in each collection period, repeated use of sites meant that faunal densities in the 4 collection periods were not independent. We therefore did not pool data across collection periods, as pooling data would violate the regression assumption that data points are obtained from independent samples (Zar 1984, Underwood 1997). Additionally, the large differences in faunal densities and seagrass biomass between seasons and years (see 'Results: Faunal densities and environmental variables' below) suggested that pooling all samples would produce an ill fit to the data, and pooling would preclude testing how correlations between faunal densities and environmental variables varied through time. Therefore, we conducted separate multiple regressions for each collection period in order to compare the effects of the environmental variables on species' densities between spring and fall and between 1991 and 1992. Visual examination of residuals revealed that data transformation was not necessary to meet the statistical assumptions for regressions (Chatterjee \& Price 1991).

Before conducting full multiple regressions, we used simple linear or quadratic regression models to examine the relationships between the independent variables. We used the residuals from any significant regressions as independent variables in the full analyses (Villard et al. 1999). This enabled us to (1) test for independent effects of each variable (i.e. eliminate covariation with other environmental variables), and (2) eliminate multicollinearity caused by correlation between the independent variables, which inflates the variance of the regression coefficients and increases Type II error (Zar 1984, Johnson \& Wichern 1992). For instance, REI and seagrass percent cover were highly correlated, and we used the residuals from the linear regression as a new independent variable to determine

Table 1. Environmental (i.e. explanatory) variables used in the multiple regression analyses. Explanatory variables were used in the multiple regression model in raw form ('raw') when not correlated with other explanatory variables or as residuals from significant regressions with other explanatory variables ('residual'). REI: relative wave exposure index

\begin{tabular}{|c|c|c|c|}
\hline Variable name & Correlation & Type of data & Model \\
\hline REI & None & Raw & - \\
\hline Mean water depth & None & Raw & - \\
\hline Percent seagrass cover & REI & Residual & Linear $^{\mathrm{a}}$ \\
\hline Total linear edge & Percent seagrass cover & Residual & Quadratic $^{b}$ \\
\hline Seagrass shoot density & None & Raw & - \\
\hline Seagrass shoot biomass & None & Raw & - \\
\hline Percent organic matter & REI & Residual & Linear $^{c}$ \\
\hline \multicolumn{4}{|c|}{$\begin{array}{l}{ }^{\mathrm{a}} \text { Percent cover }=0.9-1.3 \times 10^{-7}(\mathrm{REI}) ; \mathrm{df}=1,67, F=56.2, \mathrm{r}^{2}=0.45, \mathrm{p}<0.001 \\
\mathrm{~b} \text { Total linear edge }=17+4632(\% \text { cover })-4575\left(\% \operatorname{cover}^{2}\right) ; \mathrm{df}=2,66, F=91.8, \mathrm{r}^{2}=0.73, \mathrm{p}<0.001 \\
{ }^{\mathrm{c}} \text { Percent organic matter }=2.74-4.2 \times 10^{-7}(\mathrm{REI}) ; \mathrm{df}=1,67, F=41.1, \mathrm{r}^{2}=0.37, \mathrm{p}<0.001\end{array}$} \\
\hline
\end{tabular}


Table 2. Epifaunal species collected in throw-traps that made up over $95 \%$ of the total catch

\begin{tabular}{|llc|}
\hline Species name & Common name & $\begin{array}{c}\text { \% of total } \\
\text { catch }\end{array}$ \\
\hline Crustaceans & & \\
$\quad$ Hippolyte spp. & Grass shrimp (G) & 45.5 \\
Alpheus normanni & $\begin{array}{c}\text { Green snapping } \\
\text { shrimp (GS) }\end{array}$ & 10.4 \\
Periclimenes & Longtail shrimp (L) & 10.2 \\
longicaudatus & Arrow shrimp(A) & 5.5 \\
Tozeuma carolinense & Pink shrimp (P) & 5.2 \\
Penaeus duorarum & Blue crab (B) & 3.7 \\
Callinectes sapidus & Big-clawed snapping & 2.4 \\
Alpheus heterochaelis & shrimp(BS) & 1.6 \\
Dyspanopeus sayi & Mud crab (M) & \\
Fishes & & 6.2 \\
Gobionellus boleosoma & Darter goby (D) & 3.1 \\
Lagodon rhomboides & Pinfish (PN) & 1.4 \\
Orthopristis chrysoptera & Pigfish (PG) & 1.1 \\
Symphurus plagiusa & Blackcheek & \\
TOTAL & tonguefish (T) & 96.3 \\
\hline & & \\
\hline
\end{tabular}

the effect of seagrass percent cover on faunal density with the effect of energy regime removed (Table 1).

Faunal and site groupings: We used principal components analysis (PCA) on the faunal data (PROC FACTOR in PC SAS 8.01) with a varimax rotation to find how species grouped by their densities and to find if sites could be grouped by species' densities. We performed separate PCAs for each collection period. Both species and sites were plotted in principal component (PC) space by their scores and the results were considered graphically (Meng \& Powell 1999).

\section{RESULTS}

\section{Faunal densities and environmental variables}

Eight decapod species and 4 fish species made up over $95 \%$ of the total catch and were included in the final analyses (Table 2). Eighty-seven percent of the 7094 individuals collected were decapods and 13\% were fishes. There generally were strong differences in faunal densities between seasons and years; only mud crab density did not differ significantly between collection periods, due to high variation in mud crab densities between sites in 1991 (Fig. 2). Differences in faunal densities between collection periods varied greatly between the 12 species. However, there was a trend for faunal densities to be higher in fall than in spring, and higher in 1992 than in 1991, except for pin-
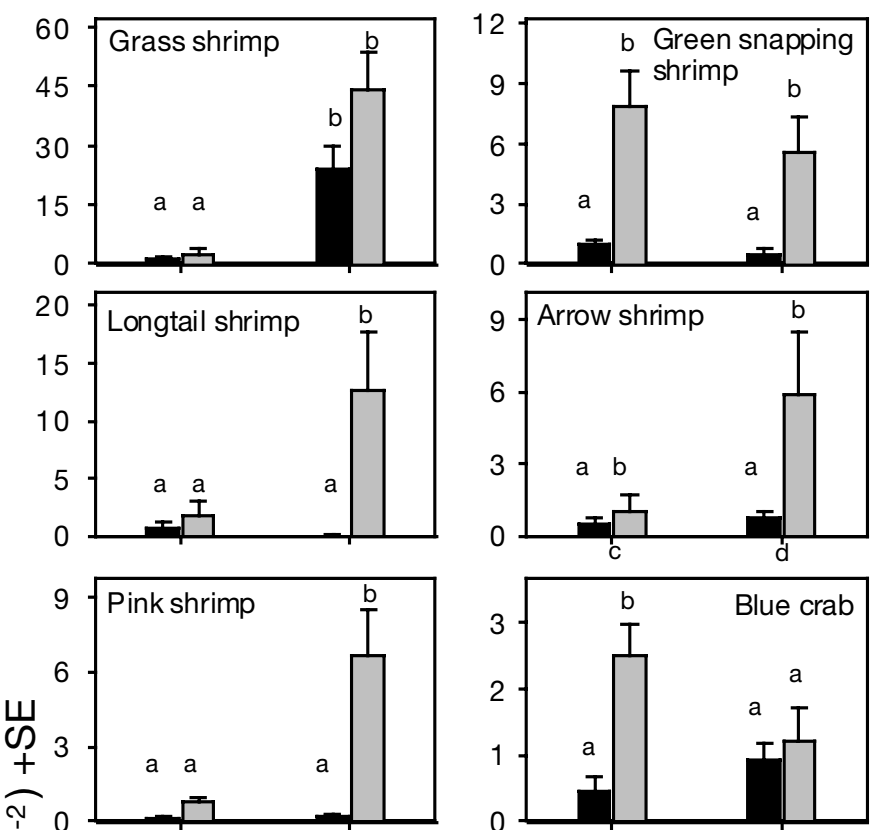

토
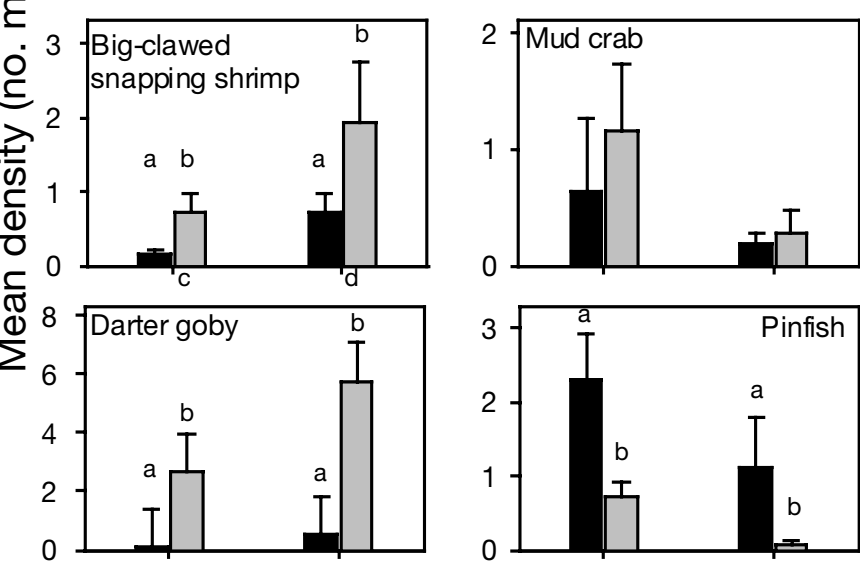

$\frac{\varnothing}{\mathbb{\Phi}}$
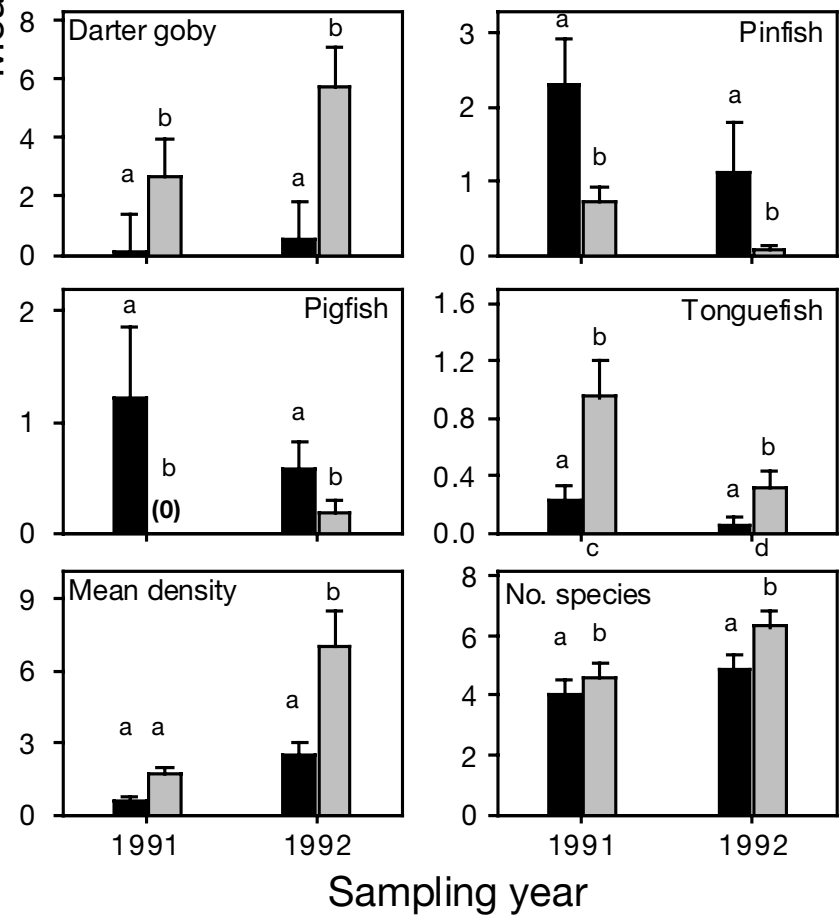

Fig. 2. Mean ( \pm standard error [SE]) densities of 12 epifaunal species collected in throw-traps in spring (May to June; gray columns) and fall (November; black columns) 1991 and 1992. Unlike letters above and below bars denote significant differences between means at $\mathrm{p}<0.05$ as determined by SNK tests 

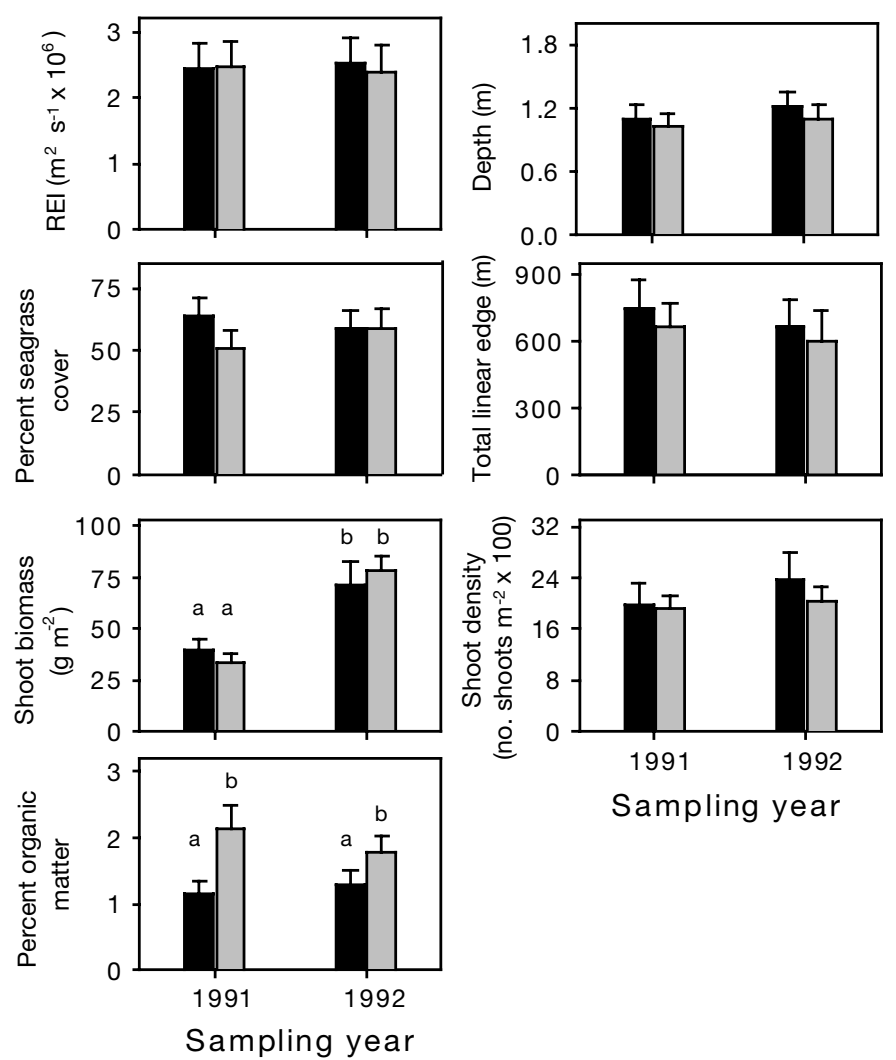

Fig. 3. Means $( \pm \mathrm{SE})$ for the 7 environmental variables used as independent variables in the multiple regression analyses for spring (May to June; black colums) and fall (November; gray colums) 1991 and 1992. Unlike letters above bars denote significant differences between means at $\mathrm{p}<0.05$ as determined by SNK tests. REI: relative wave exposure index

fish and pigfish densities, which were higher in spring than in fall in both years (Fig. 2). The mean density of all species combined was significantly higher in fall than in spring in 1992 but not in 1991, and significantly higher in the fall of 1992 than in the fall of 1991. The mean number of species found at sites was significantly greater in fall than in spring in both years.

REI, depth, percent seagrass cover, total linear edge and shoot density did not vary significantly between collection periods (Fig. 3). However, seagrass shoot biomass was significantly higher in 1992 than in 1991, and percent organic matter was higher in fall than in spring in both years (Fig. 3).

\section{Faunal-environmental correlations}

Generally, there were relatively few significant correlations between faunal species densities and environmental variables (21 out of 56 regressions in which density was significantly correlated with at least 1 independent variable; Tables $3 \& 4$ ). Most significant regressions involved only 1 environmental variable, and no regressions had over 2 significant environmental variables. Relationships between faunal densities and environmental variables varied greatly between species and between collection periods, and speciesspecific correlations between faunal density and environmental variables generally were not consistent between sampling periods. Of the 7 environmental variables tested, REI (10 correlations) and seagrass shoot biomass ( 8 correlations) appeared to have the greatest influence on species' densities, with REI having more influence on densities in 1991 and shoot biomass having more influence on densities in 1992 (Tables 3 \& 4). Correlations between faunal densities and seagrass shoot biomass were present only in 1992,

Table 3. Results from multiple regression analyses of species densities, total abundance and number of species loaded on environmental variables for 1991. Sign of the coefficient is in parentheses followed by the partial $\mathrm{r}^{2}$ for each variable. Only significant $(p<0.05)$ correlations are shown. F: fall; S: spring. ${ }^{*} \mathrm{p}<0.05,{ }^{* *} \mathrm{p}<0.01,{ }^{* * *} \mathrm{p}<0.001$

\begin{tabular}{|c|c|c|c|c|}
\hline Species & Season & Variable & $\begin{array}{l}\text { Partial } \\
\mathrm{r}^{2}\end{array}$ & $\begin{array}{c}\text { Total } \\
\text { model } \mathrm{r}^{2}\end{array}$ \\
\hline Grass shrimp & $\begin{array}{l}\mathrm{S} \\
\mathrm{F}\end{array}$ & $\begin{array}{l}\text { None } \\
\text { None }\end{array}$ & & \\
\hline $\begin{array}{l}\text { Green snapping } \\
\text { shrimp }\end{array}$ & $\begin{array}{l}\mathrm{S} \\
\mathrm{F}\end{array}$ & $\begin{array}{l}\text { None } \\
\text { REI (-) }\end{array}$ & $0.26^{*}$ & $0.26^{*}$ \\
\hline Longtail shrimp & $\begin{array}{l}\mathrm{S} \\
\mathrm{F}\end{array}$ & $\begin{array}{l}\text { None } \\
\text { None }\end{array}$ & & \\
\hline Arrow shrimp & $\begin{array}{l}\mathrm{S} \\
\mathrm{F}\end{array}$ & $\begin{array}{c}\text { None } \\
\text { Depth }(+) \\
\text { Organic }(+)\end{array}$ & $\begin{array}{l}0.71^{* * *} \\
0.08^{*}\end{array}$ & $0.79^{* * *}$ \\
\hline Pink shrimp & $\begin{array}{l}\mathrm{S} \\
\mathrm{F}\end{array}$ & $\begin{array}{l}\text { Organic }(+) \\
\text { None }\end{array}$ & $0.43^{* *}$ & $0.43^{* *}$ \\
\hline Blue crab & $\begin{array}{l}\mathrm{S} \\
\mathrm{F}\end{array}$ & $\begin{array}{l}\text { REI }(-) \\
\text { Depth }(+) \\
\text { None }\end{array}$ & $\begin{array}{l}0.35^{* *} \\
0.26^{* *}\end{array}$ & $0.61^{* * *}$ \\
\hline $\begin{array}{l}\text { Big-clawed } \\
\text { snapping shrimp }\end{array}$ & $\begin{array}{ll}\mathrm{S} \\
\mathrm{p}\end{array}$ & $\begin{array}{l}\text { None } \\
\text { None }\end{array}$ & & \\
\hline Mud crab & $\begin{array}{l}\mathrm{S} \\
\mathrm{F}\end{array}$ & $\begin{array}{l}\text { REI (+) } \\
\text { None }\end{array}$ & $0.26^{*}$ & $0.26^{*}$ \\
\hline Darter goby & $\begin{array}{l}\mathrm{S} \\
\mathrm{F}\end{array}$ & $\begin{array}{l}\text { None } \\
\text { REI (-) }\end{array}$ & $0.28^{*}$ & $0.28^{*}$ \\
\hline Pinfish & $\begin{array}{l}\mathrm{S} \\
\mathrm{F}\end{array}$ & $\begin{array}{c}\text { None } \\
\text { REI (-) } \\
\text { Edge (-) }\end{array}$ & $\begin{array}{l}0.42^{* *} \\
0.16^{*}\end{array}$ & $0.58^{* *}$ \\
\hline Pigfish & $\begin{array}{l}\mathrm{S} \\
\mathrm{F}\end{array}$ & $\begin{array}{l}\text { None } \\
\text { None }\end{array}$ & & \\
\hline $\begin{array}{c}\text { Blackcheek } \\
\text { tonguefish }\end{array}$ & $\stackrel{\mathrm{S}}{\mathrm{F}}$ & $\begin{array}{l}\text { None } \\
\text { None }\end{array}$ & & \\
\hline Total abundance & $\begin{array}{l}\mathrm{S} \\
\mathrm{F}\end{array}$ & $\begin{array}{l}\text { None } \\
\text { REI (-) }\end{array}$ & $0.36^{*}$ & $0.36^{*}$ \\
\hline No. species & $\begin{array}{l}\mathrm{S} \\
\mathrm{F}\end{array}$ & $\begin{array}{c}\text { None } \\
\text { REI (-) } \\
\text { Cover (+) }\end{array}$ & $\begin{array}{l}0.23^{*} \\
0.23^{*}\end{array}$ & $0.46^{*}$ \\
\hline
\end{tabular}


when shoot biomass was high. Landscape-scale variables (percent seagrass cover or total seagrass linear edge) were related only to the densities of blue crabs and pinfish and the total number of species in the fall of 1991, or the spring of 1992, and therefore appeared to have relatively little influence on species' densities overall.

There were few significant correlations between faunal densities and environmental variables in the spring of 1991 when the overall abundance of fauna was low; only blue crab density (negative correlation with REI and positive correlation with depth), mud crab density (positive correlation with REI) and grass shrimp density (positive correlation with percent organic matter) were related to environmental variables (Table 3). In the fall of 1991, densities of green snapping shrimp, darter goby and pinfish, along with total abundance and number of species, were negatively correlated with REI. Both blue crab and arrow shrimp densities were positively correlated with depth, and arrow shrimp density also was positively correlated with percent organic matter. Pinfish density was negatively associated with total linear edge, and the total number of species was positively correlated with seagrass percent cover (Table 3).

In the spring of 1992, pink shrimp, grass shrimp, bigclawed snapping shrimp and total abundance all were positively correlated with seagrass shoot biomass (Table 4). Darter goby densities and number of species were negatively correlated with REI, but mud crab density was positively correlated with REI, as it was in the spring of 1991. Blue crab density was positively correlated with seagrass percent cover. In the fall of 1992, grass shrimp, arrow shrimp, total abundance and number of species all were positively correlated with seagrass shoot biomass, and longtail shrimp density was positively correlated with depth (Table 4).

\section{Principal components analyses}

\section{Species groupings}

Species' loadings on the first 3 PCs and the amount of standardized variance accounted for by each PC are shown in Fig. 4. Generally, there was little consistency in species' groupings between collection periods; species that grouped together in one collection period tended not to group together in other collection periods. There was moderate separation between crustacean species and fish species in PC space in the spring of 1991 but very little separation between crustaceans and fishes in the other collection periods.

In the spring of 1991, longtail shrimp, arrow shrimp, pink shrimp and darter goby loaded high on PC1.
These species all were moderately abundant and are associated with the seagrass canopy. Pinfish and pigfish were abundant in the spring of 1991, and both loaded high on PC2, along with total abundance. Green snapping shrimp and mud crabs, both cryptic species, loaded high on PC3. Grass shrimp and bigclawed snapping shrimp loaded high on PC4, and blue crabs loaded high on PC5.

In the fall of 1991, green snapping shrimp, darter goby, pinfish and total abundance all had high loadings on PC1, and all were negatively associated with REI in multiple regressions. Longtail shrimp and blackcheek tonguefish loaded high on PC2, and pink shrimp, big-clawed snapping shrimp and number of species loaded high on PC3. Grass shrimp, arrow shrimp and blue crabs loaded high on PC4, and mud crabs loaded high on PC5.

In the spring of 1992, pinfish, blackcheek tonguefish and number of species had high loadings on PC1, but

Table 4. Results from multiple regression analyses of species densities, total abundance and number of species loaded on environmental variables for 1992. Sign of the coefficient is in parentheses followed by the partial $\mathrm{r}^{2}$ for each variable. Only significant correlations are shown. F: fall; S: spring. ${ }^{*} p<0.05$, ${ }^{* *} \mathrm{p}<0.01,{ }^{* * *} \mathrm{p}<0.001$

\begin{tabular}{|c|c|c|c|c|}
\hline Species & Season & Variable & $\begin{array}{l}\text { Partial } \\
\mathrm{r}^{2}\end{array}$ & $\begin{array}{c}\text { Total } \\
\text { model } r^{2}\end{array}$ \\
\hline \multirow[t]{2}{*}{ Grass shrimp } & $\mathrm{S}$ & Biomass (+) & $0.45^{* *}$ & $0.45^{* *}$ \\
\hline & $\mathrm{F}$ & Biomass (+) & $0.45^{*}$ & $0.45^{*}$ \\
\hline \multirow{2}{*}{$\begin{array}{l}\text { Green snapping } \\
\text { shrimp }\end{array}$} & $\mathrm{S}$ & None & & \\
\hline & $\mathrm{F}$ & None & & \\
\hline \multirow[t]{2}{*}{ Longtail shrimp } & $\mathrm{S}$ & None & & \\
\hline & $\mathrm{F}$ & Depth $(+)$ & $0.84^{* * *}$ & $0.84^{* * *}$ \\
\hline \multirow[t]{2}{*}{ Arrow shrimp } & $\mathrm{S}$ & None & & \\
\hline & $\mathrm{F}$ & Biomass $(+)$ & $0.49^{* *}$ & $0.49^{* *}$ \\
\hline Pink shrimp & $\begin{array}{l}\mathrm{S} \\
\mathrm{F}\end{array}$ & $\begin{array}{c}\text { Biomass }(+) \\
\text { None }\end{array}$ & $0.38^{* *}$ & $0.38^{* *}$ \\
\hline Blue crab & $\begin{array}{l}S \\
F\end{array}$ & $\begin{array}{l}\text { Cover (+) } \\
\text { None }\end{array}$ & $0.42^{* *}$ & $0.42^{* * *}$ \\
\hline \multirow{2}{*}{$\begin{array}{l}\text { Big-clawed } \\
\text { snapping shrimp }\end{array}$} & $\mathrm{S}$ & Biomass (+) & $0.39^{* *}$ & $0.39^{* *}$ \\
\hline & o F & None & & \\
\hline Mud crab & $\begin{array}{l}\mathrm{S} \\
\mathrm{F}\end{array}$ & $\begin{array}{l}\text { REI (+) } \\
\text { None }\end{array}$ & $0.26^{*}$ & $0.26^{*}$ \\
\hline Darter goby & $\begin{array}{l}\mathrm{S} \\
\mathrm{F}\end{array}$ & $\begin{array}{l}\text { REI (-) } \\
\text { None }\end{array}$ & $0.45^{* *}$ & $0.45^{* *}$ \\
\hline Pinfish & $\begin{array}{l}\mathrm{S} \\
\mathrm{F}\end{array}$ & $\begin{array}{l}\text { None } \\
\text { None }\end{array}$ & & \\
\hline Pigfish & $\begin{array}{l}\mathrm{S} \\
\mathrm{F}\end{array}$ & $\begin{array}{l}\text { None } \\
\text { None }\end{array}$ & & \\
\hline $\begin{array}{r}\text { Blackcheek } \\
\text { tonguefish }\end{array}$ & $\begin{array}{l}\mathrm{S} \\
\mathrm{F}\end{array}$ & $\begin{array}{l}\text { none } \\
\text { None }\end{array}$ & & \\
\hline Total abundance & $\begin{array}{l}\mathrm{S} \\
\mathrm{F}\end{array}$ & $\begin{array}{l}\text { Biomass }(+) \\
\text { Biomass }(+)\end{array}$ & $\begin{array}{l}0.39^{* *} \\
0.55^{* *}\end{array}$ & $\begin{array}{l}0.39^{* *} \\
0.55^{* *}\end{array}$ \\
\hline No. species & $\begin{array}{l}\mathrm{S} \\
\mathrm{F}\end{array}$ & $\begin{array}{c}\text { REI (-) } \\
\text { Biomass (+) }\end{array}$ & $\begin{array}{l}0.36^{*} \\
0.35^{*}\end{array}$ & $\begin{array}{l}0.36^{*} \\
0.35^{*}\end{array}$ \\
\hline
\end{tabular}


(A)

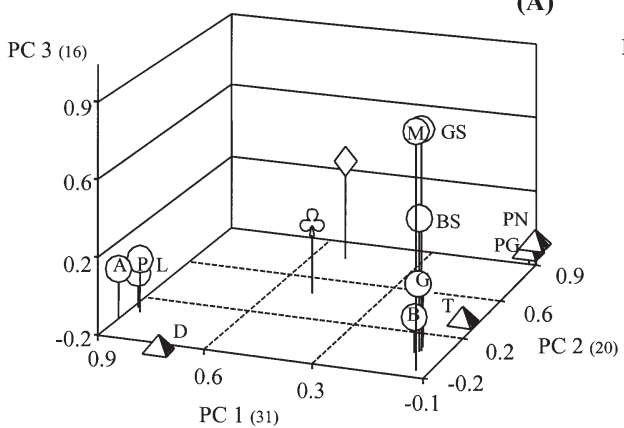

(B)

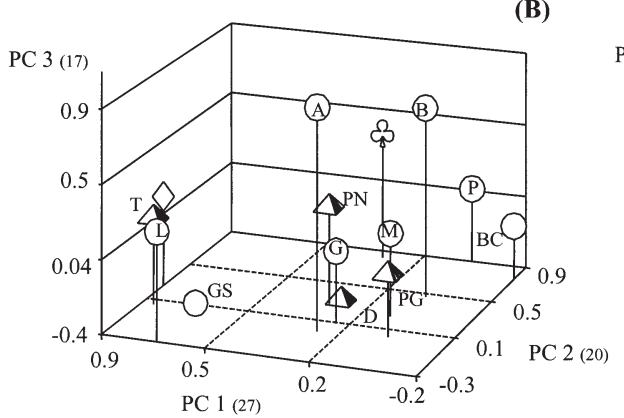

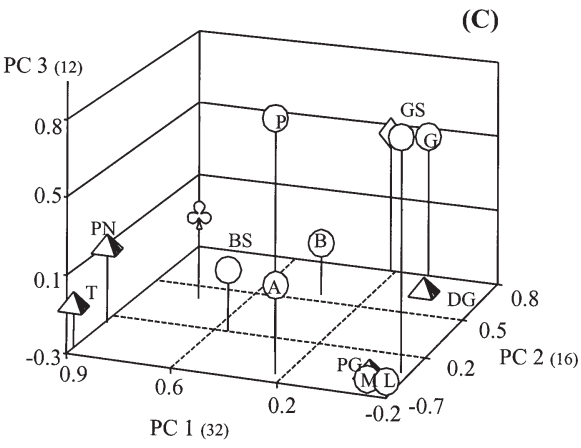

(D)

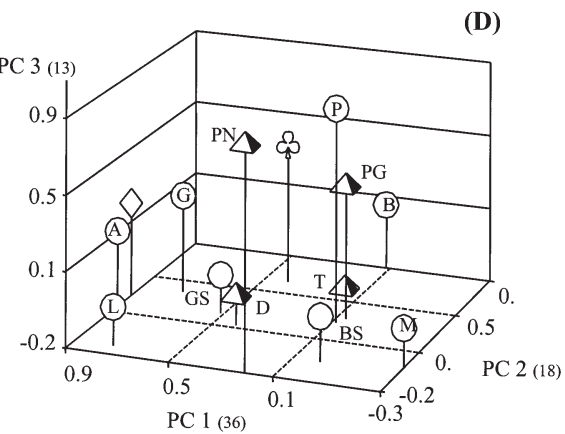

Fig. 4. Species groupings as determined by principal components analysis on 8 crustacean and 4 fish species in (A) spring 1991, (B) fall 1991, (C) spring 1992 and (D) fall 1992. Only the first 3 principal components are shown. Balloon indicates crustaceans, pyramid indicates fishes, diamond indicates total abundance, and cloverleaf indicates number of species. Letters next to symbols denote species codes as listed in Table 2, and numbers in parentheses denote the amount of standardized variance accounted for by each principal component (PC) other fish species (pinfish and pigfish) had low loadings on PC1. Grass shrimp, which were the most abundant species in the spring of 1992, and total abundance had high loadings on PC2, though darter gobies, which were not especially abundant, also loaded high on PC2. Green snapping shrimp and pink shrimp had high loadings on PC3, longtail shrimp and arrow shrimp had high loadings on $\mathrm{PC} 4$, and pigfish had high loadings on PC5.

In the fall of 1992, the first PC appeared to separate species by abundance: extremely abundant grass shrimp and longtail shrimp, along with total abundance and arrow shrimp, all had high loadings on PC1. All of these species except longtail shrimp also were positively correlated with seagrass biomass. Blue crabs and blackcheek tonguefish, both of which hide in shallow mud and prey upon small meiofauna as juveniles, and number of species all had high loadings on PC2. Pink shrimp and pinfish, relatively fast swimmers associated with the seagrass canopy, had high loadings on PC3. Cryptic green snapping shrimp and mud crabs loaded high on PC4; these 2 species also grouped together in the spring of 1991. Big-clawed snapping shrimp and darter gobies had high loadings on PC5.

\section{Site groupings}

Grouping of sites in PC space by faunal densities is shown in Fig. 5. There was an obvious separation of sites with higher than average faunal densities from sites with lower than average faunal densities in all 4 collection periods. One or 2 sites with the highest densities loaded very high on PC1, whereas most other sites had low loadings on PC1 in all 4 analyses. High density sites also loaded higher on PC2 than did low density sites, though this pattern was not as apparent in the fall of 1991 as in the other collection periods.

\section{DISCUSSION}

Though positive relationships between faunal abundance and structural components of seagrass beds such as shoot biomass and shoot density are common (Heck \& Orth 1980, Lewis \& Stoner 1983, Bell \& Westoby 1986, Attrill et al. 2000), few studies have measured the effects of large-scale habitat structure (e.g. percent cover, edge, patch size) and energy regime on faunal abundance in seagrass habitats (but see Turner et al. 1999). Moreover, local- and landscape-scale seagrass habitat structure are strongly related to hydrodynamic activity, and this covariation makes it difficult to determine which processes are chiefly responsible for shaping faunal communities. We statistically removed the confounding among these variables and considered the singular influences of landscape-scale seagrass structure, local-scale seagrass structure and hydrodynamic activity on the abundance of common seagrass fauna in the spring and fall of 1991 and 1992. 
Despite our selection of sampling sites that maximized variation in seagrass cover (range of 13 to $100 \%$ ), we found little influence of landscape-scale habitat features on faunal abundance and large differences between collection periods and between species in the effects of environmental variables on faunal densities. When correlations existed, faunal densities were most strongly related to energy regime and local-scale $(<1 \mathrm{~m})$ habitat features.

\section{Environmental effects on fauna}

Spatial patterning of habitats at the landscape scale often has strong effects on processes such as predation that influence faunal abundance. High rates of nest predation and parasitism are found in fragmented forests where songbird abundance is reduced (Brittingham \& Temple 1983, Wilcove 1985, Small \& Hunter 1988, Johnson \& Temple 1990, Andrén 1992, Robinson et al. 1995). Landscape structure also may be an important determinant of faunal abundance and survival in marine systems. Bivalve survival was reduced in small seagrass patches (Irlandi 1997) and in areas of low seagrass cover (Irlandi 1994, Irlandi et al. 1995) in Back Sound, and blue crab survival and density were lowest in seagrass patches of intermediate size in Chesapeake Bay (Hovel \& Lipcius 2002). However, seagrass structural complexity, patch size and percent cover covaried in those studies, making it difficult to single out the influence of structure at any one spatial scale on survival or abundance. Here, we eliminated covariation in seagrass structure at local and landscape scales and found a greater influence of shoot biomass on faunal densities than seagrass percent cover or total linear edge. Moreover, we found that hydrodynamic regime influences the density of a variety of fauna after covarying effects of landscape structure are removed. Irlandi (1997) used artificial seagrass to standardize structural complexity and found no difference in juvenile hard clam survival between patch sizes, and suggested that variation in local-scale habitat structure may be responsible for differences in clam survival between patch sizes. Hovel \& Lipcius (2001) also used artificial seagrass to standardize structural complexity among seagrass patch sizes, but found a strong negative influence of patch size on juvenile blue crab survival in Chesapeake Bay. Collectively, these results and those presented herein suggest that (1) a variety of environmental factors may independently influence faunal survival or abundance, (2) there is no overriding influence of any one factor on processes influencing faunal abundance, and (3) the influence of any one factor on fauna may vary greatly through space and time and with species. More studies are needed that examine independent effects of covarying factors on fauna in seagrass habitats to determine whether their influences can be generalized or are primarily species- and context-specific.

The influence of environmental variables on faunal densities differed greatly between seasons and years. In 1991, there was a significant negative influence of REI on the densities of green snapping shrimp, blue crabs, darter gobies and pinfish, in addition to total
Fig. 5. Site groupings as determined by principal components analysis on 8 crustacean and 4 fish species in (A) spring 1991, (B) fall 1991, (C) spring 1992 and (D) fall 1992. Only the first 3 principal components are shown. Balloon indicates sites with epifaunal densities $>50$ ind $\mathrm{m}^{-2}$, and pyramid indicates sites with epifaunal densities $<50$ ind. $\mathrm{m}^{-2}$
(A)

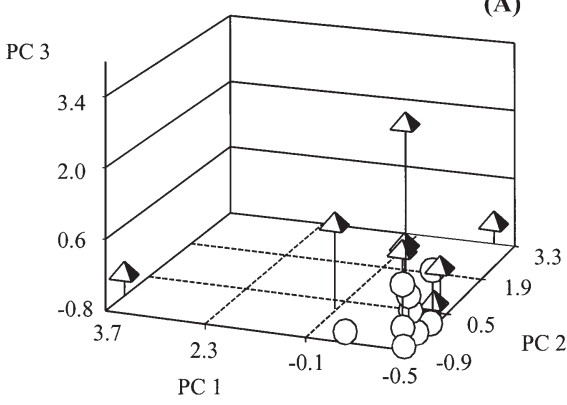

(B)

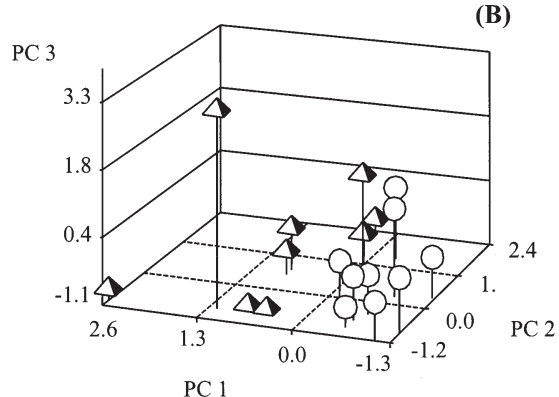

(C)

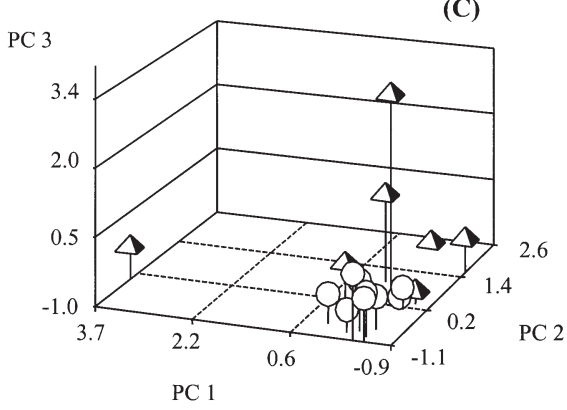

(D)

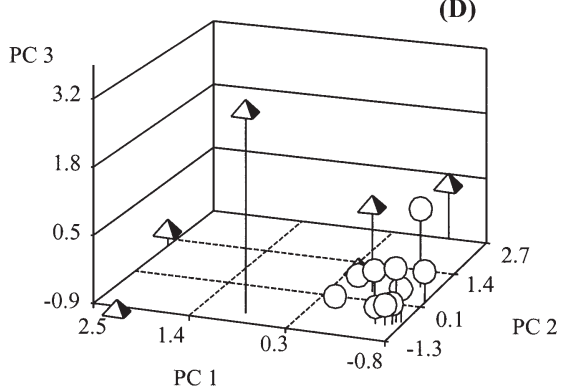


abundance and number of species. Though mean REI did not vary between seasons or years (Fig. 3), hydrodynamic regime had relatively little influence on fauna in 1992. Hydrodynamic setting may influence faunal abundance indirectly by modifying seagrass (e.g. canopy geometry, percent cover, patch size) or sediment characteristics (e.g. sediment organic content and silt-clay; Fonseca \& Bell 1998). However, our results suggest that waves and currents may have directly influenced the density of some crustaceans and fishes, perhaps by influencing feeding rates (Bell et al. 1994), larval availability and settlement (Bell \& Westoby 1986, Sogard et al. 1987, Orth 1992, Worthington et al. 1992) or locomotion (Vogel 1994). Except for mud crabs, REI had a negative influence on fauna, which suggests that at the landscape scale waves and currents may interfere with feeding and movement. Working in Florida and North Carolina, Bell et al. (1994) suggested that lower copepod (i.e. prey) densities in high energy sites may at least in part have been responsible for lower mean fish density and number of fish species in high- than in low-energy sites.

Seagrass shoot biomass strongly influenced shrimp densities in 1992 but was correlated with the density of no species in 1991. Unlike REI, however, mean shoot biomass was significantly higher in 1992 than in 1991 (Fig. 3). Mean shoot biomass in 1992 therefore may have been above some threshold level at which biomass has a positive effect on the densities of canopydwelling species. High levels of shoot biomass provide more living space for epifauna, thereby increasing faunal abundance and diversity (Stoner 1980, 1983, Attrill et al. 2000). The abundance of small epibenthic and epiphytic organisms that serve as food for macrofauna such as shrimp, crabs and fishes may increase with shoot density or biomass (Orth 1992). Dense seagrass shoots interfere with predator search and capture of prey (see reviews by Orth et al. 1984, Heck \& Crowder 1991) and thus areas of high structural complexity serve as refuges from predation for many species. Here, shrimp densities were highly correlated with seagrass shoot biomass, but not with shoot density, suggesting that the amount of plant material (and correspondingly the amount of living space and food) has a greater influence on abundance than the number of shoots in a given area (see also Attrill et al. 2000).

In contrast to our study, seagrass shoot biomass and other patch-scale variables explained little ( 2 to $4 \%$ ) of the variation in seagrass faunal abundance, whereas landscape and wave exposure variables explained $>60 \%$ of the variance in abundance in New Zealand (Turner et al. 1999). A comparison of these results indicates that the scale dependency of faunal responses to environmental variables may differ greatly between seagrass landscapes. Factors leading to landscapespecific responses may include variation in faunal community structure, variation in seagrass spatial patterning at multiple scales, the degree of exposure to waves and currents, and differences in the scale at which samples are collected.

Of the species we collected, only the commercially important blue crab (Hovel 1999, Hovel \& Lipcius 2001) has been used in previous studies comparing the effects of landscape structure and structural complexity on survival and abundance. Nearly all blue crabs captured in our $1 \mathrm{~m}^{2}$ throw-traps were juveniles (ca. 5 to $50 \mathrm{~mm}$ carapace width), which are vulnerable to larger conspecifics and other predators (Moody 1994, Hovel \& Lipcius 2001). Blue crab density was positively correlated with seagrass percent cover in the spring of 1992 but never with local-scale habitat characteristics. In contrast, Hovel (1999) found no correlation between juvenile blue crab abundance and seagrass cover in Chesapeake Bay; instead, juvenile blue crab abundance was positively correlated with seagrass shoot density. Though continuous seagrass cover may reduce predation rates on some seagrass fauna (e.g. Irlandi 1994, 1997), crab survival was lower in continuous seagrass habitat than in fragmented habitat in Chesapeake Bay (Hovel \& Lipcius 2001) and in North Carolina (K. A. Hovel unpubl. data). Relationships between juvenile blue crab abundance and habitat structure therefore are variable and may be difficult to predict.

Though local-scale, landscape-scale and water motion variables all influenced the density of some epifauna in our study, our multiple regression equations accounted for only a moderate amount of the variance in faunal densities in each sampling period (mean $\mathrm{r}^{2}=$ 0.44 , standard deviation $[S D]=0.15)$. Similarly, the densities of 6 fish species from Florida Bay were correlated with physical factors and aspects of seagrass architecture, but the explanatory power of multiple regressions was relatively low (Sogard et al. 1987). This low explanatory power may arise simply because seagrass faunal densities are influenced by a variety of covarying processes associated with seagrass structure and energy regime, which also may be operating with varying influence as a function of spatial scale. Hydrodynamic activity, seagrass landscape structure (e.g. canopy geometry, percent cover, patch size), sediment characteristics (e.g. sediment organic content) and elements of seagrass structural complexity such as shoot density and biomass all may influence predation (Orth \& van Montfrans 1982, Orth et al. 1984, Heck \& Crowder 1991), competition (Coen et al. 1981), the amount of habitat available (Attrill et al. 2000), food availability (Edgar 1990) and active selection of habitat (Bell \& Westoby 1986, Sogard 1989). Moreover, faunalhabitat associations at small spatial scales may not 
exist over larger scales, perhaps due to patchy distributions of settling larvae (Bell \& Westoby 1986, Sogard et al. 1987, Worthington et al. 1992) or faunal movement from patch to patch (Sogard 1989). Therefore, in contrast to many terrestrial landscapes, complex interactions between a variety of processes across several spatial scales may limit the extent to which faunal densities in seagrass habitats are correlated with landscape-scale structure, even if strong relationships exist between structure and key interactions such as predation.

\section{Faunal densities}

The mean density of all species except mud crabs varied significantly between seasons or years (Fig. 2). Our data indicate that, in general, differences in species' densities between collection periods did not conform to differences in environmental variables. Though percent organic matter and green snapping shrimp, arrow shrimp, big-clawed snapping shrimp, darter goby and tonguefish densities all were higher in the fall than in the spring in both years, the density of none of these species was correlated with percent organic matter in multiple regressions (except for a very weak correlation between arrow shrimp density and percent organic matter in the fall of 1991; Table 3). However, seagrass shoot biomass and densities of grass shrimp, arrow shrimp and big-clawed snapping shrimp all were significantly higher in 1992 than in 1991, and the densities of all of these species were influenced by shoot biomass. We speculate that differences in faunal densities between seasons and between years are determined more by pre-settlement factors (e.g. larval abundance and current regimes) or by environmental factors not examined in our study than by the variables we included in our analyses, except perhaps for shoot biomass. Because our sampling spanned only $2 \mathrm{yr}$, our study is not intended to provide broad generalizations about variation in faunal densities between seasons and between years but instead focuses on differences and consistencies in environmental effects between the 4 collection periods.

\section{Faunal groupings}

We used PCA to group both species and sites on the basis of faunal densities. There was little consistency in species groupings between sampling periods, and little separation between crustaceans and fishes (Figs. 4 \& 5). Within individual sampling periods, species sometimes grouped by their association with environmental variables (e.g. REI: fall 1991) or on the basis of abundance (fall 1992). Grouping of sites on the basis of faunal abundance was evident in all 4 sampling periods; sites with high overall faunal abundance were clearly distinguishable from sites with low overall faunal abundance. Sites with high faunal abundance exhibited broad variability in environmental characteristics (e.g. percent cover, shoot density and shoot biomass). However, high abundance sites and low abundance sites generally were geographically distinct; with 1 exception, high abundance sites (black circles in Fig. 1) clustered in western Back Sound near Beaufort Inlet. Sites with average to low abundance (black-and-white circles in Fig. 1) were found primarily to the east in Core Sound. These sites are influenced by tidal flow entering the estuary through Barden's Inlet (authors' pers. obs.). We hypothesize that the proximity to and dominance of tidal flow through different inlets may contribute to the geographic differences in fauna, perhaps due to different recruitment patterns. Tidal flow entering through Beaufort Inlet dominates the circulation throughout Back Sound and into southern Core Sound (authors' pers. obs.). This hypothesis implies that processes operating over larger spatial scales than considered here (i.e. kilometers) may play a role in determining faunal abundance. In Rhode Island, juvenile fish habitats grouped according to distance to the ocean and the amount of energy shaping the habitat over scales of several kilometers (Meng \& Powell 1999). Samples taken across several estuaries in New South Wales, Australia, revealed that variation in fish and decapod densities was not explained by seagrass structural complexity but was more consistent with a model of differential larval settlement between sites (Worthington et al. 1992). Bell \& Westoby (1986) also found that seagrass leaf density effects on fauna within individual seagrass patches were not present over larger (i.e. baywide) spatial scales. Salinity and sediment characteristics (Szedlmayer \& Able 1996) and circulation patterns (Sogard et al. 1987) often vary at baywide scales and may be partly responsible for differences in faunal communities between sites. Here, faunal densities generally were not related to sediment characteristics, and salinity is relatively constant in space and time in our study area (Hettler 1989). It remains to be determined if these site groupings persist over time and what factors may be chiefly responsible for determining abundance at larger scales, although proximity to inlets seems a logical starting point based on geographic groupings.

\section{Caveats}

Caveats to the study involve the fact that we examined links between faunal densities and landscape 
structure only at $50 \mathrm{~m} \times 50 \mathrm{~m}$ scales. Relationships between abundance and landscape structure might have been more robust than reported here if our sampling had been conducted over larger spatial extents. Differences in vagility, size, life history, resource use and vulnerability to predators between species all may influence the scale at which densities are linked to habitat attributes, and different scales therefore may be appropriate for different species. However, faunal densities (small fishes, crabs and shrimp) were linked to habitat attributes at scales used here in previous studies (Bell et al. 1994, Murphey \& Fonseca 1995). Additionally, we chose to compare the influence of landscape structure, structural complexity and water motion on species densities but did not consider alternative habitat attributes such as food levels (Bell et al. 1994) or predator abundance (Hovel \& Lipcius 2001) that may influence faunal abundance and composition. Finally, we conducted linear multiple regressions for each species, yet some relationships between faunal abundance and environmental variables may be non-linear (Sogard et al. 1987). In particular, seagrass shoot density may have a non-linear effect on survival (Orth 1992) and therefore faunal densities. We examined the scatterplots of species densities versus seagrass shoot density and found no evidence of non-linear effects. However, it is possible that other faunal-environmental relationships were not detected due to non-linearity.

\section{Implications}

Seagrass loss due to decreasing water quality (Orth \& Moore 1983, Dennison et al. 1993) and boat damage (Sargent et al. 1995) is widespread, prompting many efforts to restore degraded seagrass habitats through shoot transplantation (Fonseca et al. 1998). Forecasting relationships between faunal abundance and aspects of seagrass habitat is crucial because the goal of many habitat restoration efforts is to replenish critical nursery habitat for exploited species. Our results indicate that aspects of habitat structure at the landscape scale may not dictate faunal abundance as commonly as does hydrodynamic activity and structure at small spatial scales (e.g. shoot biomass). Hydrodynamic activity, as measured by exposure to wind waves, also strongly influences the likelihood that planted seagrass will persist (Fonseca et al. 1998). Thus, our data suggest that it is critical to determine local hydrodynamic regime when planning seagrass restoration projects and that habitat structure at local scales may be a more appropriate measure than structure at landscape scales for determining whether transplanted seagrass habitat is functionally equivalent to natural habitat (Fonseca et al. 1996, 1998).
Our results also indicate that different species or species groups may respond to different aspects of seagrass habitat. For example, juvenile blue crabs were rare in patchy, low-cover seagrass sites in this study, but these same sites of low percent cover support substantial densities of pink shrimp (Murphey \& Fonseca 1995). Similarly, in planted seagrass beds, densities of fishes and shrimps, but not crabs, displayed an asymptotic relationship with seagrass shoot density (Fonseca et al. 1996). In other seagrass ecosystems, scale dependency also may vary geographically or temporally, as illustrated by the strong effect of landscape structure on macrofaunal abundance in New Zealand (Turner et al. 1999) that was not present in our study. Additionally, fish densities likely were influenced by seagrass biomass in North Carolina but not in Florida, where the influence of macroalgal biomass dominated (Bell et al. 1994).

In conclusion, high variability in seagrass landscape structure does not necessarily correspond to variability in faunal abundance. Rather, myriad processes operating at a variety of scales may make relationships between fauna and environmental variables complex and difficult to predict. These findings are wholly unlike those of terrestrial ecosystems, where equivalent ranges of landscape structure might be expected to strongly influence faunal abundance and composition (Saunders et al. 1991, Andrén 1994).

Acknowledgements. We thank our many colleagues who helped us with field sampling, sample processing and data analysis, with special thanks to M. Crawford, M. O. Hall, S. Jensen, M. Johnson, M. LaCroix, T. Murphey, B. Robbins and E. Townsend. We are indebted to N. Maggi Kelly for her guidance and labor on the ARCINFO macro development. This work was supported by NOAA's Coastal Ocean Program, EHP-23 to M. Fonseca and S. Bell, as well as the Center for Coastal Fisheries and Habitat Research in Beaufort, North Carolina, and the National Research Council.

\section{LITERATURE CITED}

Andrén H (1992) Corvid density and nest predation in relation to forest fragmentation: a landscape perspective. Ecology 73:794-804

Andrén H (1994) Effect of habitat fragmentation on birds and mammals in landscapes with different proportions of suitable habitat: a review. Oikos 71:355-366

Attrill MJ, Strong JA, Rowden AA ( 2000) Are macroinvertebrate communities influenced by seagrass structural complexity? Ecography 23:114-121

Bell JD, Westoby M (1986) Abundance of macrofauna in dense seagrass is due to habitat preference, not predation. Oecologia (Berlin) 68:205-209

Bell SS, McCoy ED, Mushinsky HR (1991) Habitat structure: the physical arrangement of objects in space. Chapman \& Hall, New York

Bell SS, Hall MO, Fonseca MS (1994) Evaluation of faunal and 
floral attributes of seagrass beds in high and low energy regimes: a geographic comparison. In: Dryer KR, Orth RJ (eds) Changes in fluxes in estuaries. Olsen \& Olsen, Fredensborg, p 267-272

Brittingham MC, Temple SA (1983) Have cowbirds caused forest songbirds to decline? BioScience 33:31-35

Chatterjee S, Price B (1991) Regression analysis by example. Wiley \& Sons, New York

Coen LD, Heck KL Jr, Abele LG (1981) Experiments on competition and predation among shrimps of seagrass meadows. Ecology 62:1484-1493

Dennison WC, Orth RJ, Moore KA, Stevenson JC, Carter V, Kollar S, Bergstrom PW, Batiuk RA (1993) Assessing water quality with submersed aquatic vegetation. BioScience 43: 86-94

Edgar G J (1990) Population regulation, population dynamics and competition amongst mobile epifauna associated with seagrass. J Exp Mar Biol Ecol 144:205-234

Elliot NC, Kieckhefer RW, Lee JH, French BW (1998) Influence of within-field and landscape factors on aphid predator populations in wheat. Land Ecol 14:239-252

Fonseca MS, Bell SS (1998) Influence of physical setting on seagrass landscapes near Beaufort, North Carolina, USA. Mar Ecol Prog Ser 171:109-121

Fonseca MS, Meyer DL, Hall MO (1996) Development of planted seagrass beds in Tampa Bay, Florida, USA. II. Faunal components. Mar Ecol Prog Ser 132:141-156

Fonseca MS, Kenworthy WJ, Thayer GW (1998) Guidelines for the conservation and restoration of seagrasses in the United States and adjacent waters. Decision Analysis Series 12. National Oceanic and Atmospheric Administration, Silver Spring, MD

Frost MT, Rowden AA, Attrill MJ (1999) Effect of habitat fragmentation on the macroinvertebrate infaunal communities associated with the seagrass Zostera marina L. Aquat Conserv Mar Freshw Ecosyst 9:255-263

Gates JE, Gysel LW (1978) Avian nest dispersion and fledgling success in field-forest ecotones. Ecology 59:871-883

Heck KL, Crowder LB (1991) Habitat structure and predatorprey interactions. In: Bell S, McCoy E, Mushinsky H (eds) Habitat complexity: the physical arrangement of objects in space. Chapman \& Hall, New York, p 281-299

Heck KL Jr, Orth RJ (1980) Seagrass habitats: the roles of habitat complexity, competition and predation in structuring associated fish and motile macroinvertebrate assemblages. In: Kennedy VS (ed) Estuarine perspectives. Academic Press, New York, p 449-464

Hettler WF Jr (1989) Nekton use of regularly-flooded saltmarsh cordgrass habitat in North Carolina, USA. Mar Ecol Prog Ser 56:111-118

Hovel KA (1999) Effects of seagrass habitat fragmentation on juvenile blue crab survival. PhD thesis, The College of William and Mary, Williamsburg, VA

Hovel KA, Lipcius RN (2001) Habitat fragmentation in a seagrass landscape: patch size and complexity control blue crab survival. Ecology 82:1814-1829

Hovel KA, Lipcius RN (2002) Effects of seagrass habitat fragmentation on juvenile blue crab survival and abundance. J Exp Mar Biol Ecol 271:75-98

Irlandi EA (1994) Large- and small-scale effects of habitat structure on rates of predation: how percent coverage of seagrass affects rates of predation and siphon nipping on an infaunal bivalve. Oecologia 98:176-183

Irlandi EA (1997) Seagrass patch size and survivorship of an infaunal bivalve. Oikos 78:511-518

Irlandi EA, Ambrose WG Jr, Orlando BA (1995) Landscape ecology and the marine environment: how spatial config- uration of seagrass habitat influences growth and survival of the bay scallop. Oikos 72:307-313

Johnson RG, Temple SA (1990) Nest predation and brood parasitism of tallgrass prairie birds. J Wildl Manage 54: 106-111

Johnson RA, Wichern DW (1992) Applied multivariate statistical analysis, 3rd edn. Prentice Hall, Englewood Cliffs, NJ

Lewis FG III, Stoner AW (1983) Distribution of macrofauna within seagrass beds: an explanation for patterns of abundance. Bull Mar Sci 33:296-304

Meng L, Powell JC (1999) Linking juvenile fish and their habitats: an example from Narragansett Bay, Rhode Island. Estuaries 22:905-916

Moody KE (1994) Predation on juvenile blue crabs, Callinectes sapidus Rathbun, in lower Chesapeake Bay: patterns, predators, and potential impacts. PhD thesis, The College of William and Mary, School of Marine Science, Gloucester Point, VA

Murphey PL, Fonseca MS (1995) Role of high and low energy seagrass beds as nursery areas for Penaeus duorarum in North Carolina. Mar Ecol Prog Ser 121:91-98

Orth RJ (1992) A perspective on plant-animal interactions in seagrasses: physical and biological determinants influencing plant and animal abundance. In: John DM, Hawkins SJ, Price JH (eds) Plant-animal interactions in the marine benthos. Clarendon Press, Oxford

Orth RJ, Moore KA (1983) Chesapeake Bay: an unprecedented decline in submerged aquatic vegetation. Science 222:51-53

Orth RJ, van Montfrans J (1982) Predator-prey interactions in a Zostera marina (eelgrass) ecosystem in the lower Chesapeake Bay, Virginia. In: Orth RJ, van Montfrans J (eds) Interactions of resident consumers in a temperate estuarine seagrass community: Vacluse Shores, Virginia, USA. Virginia Institute of Marine Science, Gloucester Point, VA SRAMSOE 267

Orth RJ, Heck KL Jr, van Montfrans J (1984) Faunal communities in seagrass beds: a review of the influence of plant structure and prey characteristics in predator-prey relationships. Estuaries 7:339-350

Perkins-Visser E, Wolcott TG, Wolcott DL (1996) Nursery role of seagrass beds: growth of juvenile blue crabs (Callinectes sapidus Rathbun). J Exp Mar Biol Ecol 198:155-173

Petersen CGL (1918) The sea bottom and its production of fish foods; a survey of the work done in connection with valuation of Danish waters from 1883-1917. Rep Dan Biol Stn 21:1-62

Real LA, Levin SA (1991) The role of theory in the rise of modern ecology. In: Real LA, Brown JH (eds) Foundations of ecology: classic papers with commentaries. The University of Chicago Press, Chicago

Robbins BD, Bell SS (1994) Seagrass landscapes: a terrestrial approach to the marine subtidal environment. Trend Ecol Evol 9:301-304

Robinson SK, Thompson FR III, Donovan TM, Whitehead DR, Faaborg J (1995) Regional forest fragmentation and the nesting success of migratory birds. Science 267:1987-1990

Sargent FJ, Leary TJ, Crewz DW, Kruer CR (1995) Scarring of Florida's seagrasses: assessment and management options. Fla Mar Res Inst Tech Rep TR-1. Florida Marine Research Institute, St. Petersburg

Saunders DA, Hobbs RJ, Margules CR (1991) Biological consequences of ecosystem fragmentation: a review. Conserv Biol 5:18-32

Small MF, Hunter ML (1988) Forest fragmentation and avian nest predation in forested landscapes. Oecologia 76:62-64

Sogard SM (1989) Colonization of artificial seagrass by fishes 
and decapod crustaceans: importance of proximity to natural eelgrass. J Exp Mar Biol Ecol 133:15-37

Sogard SM, Powell GVN, Holmquist JG (1987) Epibenthic fish communities on Florida Bay banks: relations with physical parameters and seagrass cover. Mar Ecol Prog Ser 40:25-39

Sokal RR, Rohlf FJ (1981) Biometry, 2nd edn. WH Freeman, New York

Stoner AW (1980) The role of seagrass biomass in the organization of benthic macrofaunal assemblages. Bull Mar Sci 30:537-551

Stoner AW (1983) Distributional ecology of amphipods and tanaidaceans associated with three seagrass species. J Crust Biol 3:505-518

Szedlmayer ST, Able KW (1996) Patterns of seasonal availability and habitat use by fishes and decapod crustaceans in a southern New Jersey estuary. Estuaries 19: 697-709

Temple SA, Cary JR (1988) Modeling dynamics of habitatinterior bird populations in fragmented landscapes. Conserv Biol 2:340-347

Tewksbury JJ, Heil SJ, Martin TE (1998) Breeding productivity does not decline with increasing fragmentation in a western landscape. Ecology 79:2890-2903

Townsend EC, Fonseca MS (1998) Bioturbation as a potential mechanism influencing spatial heterogeneity of North

Editorial responsibility: Kenneth Heck (Contributing Editor), Dauphin Island, Alabama, USA
Carolina seagrass beds. Mar Ecol Prog Ser 169:123-132 Turner SJ, Hewitt JE, Wilkinson MR, Morrisey DJ, Thrush SF, Cummings VJ, Funnell, G (1999) Seagrass patches and landscapes: the influence of wind-wave dynamics and hierarchical arrangements of spatial structure on macrofaunal seagrass communities. Estuaries 22:1016-1032

Underwood AJ (1997) Experiments in ecology. Cambridge University Press, Cambridge

van Apeldoorn RC, Oostenbrink WT, van Winden A, van der Zee FF (1992) Effects of habitat fragmentation on the bank vole, Clerthionomys glareolus, in an agricultural landscape. Oikos 65:265-274

Villard M, Trzcinski MK, Merriam G (1999) Fragmentation effects on forest birds: relative influence of woodland cover and configuration on landscape occupancy. Conserv Biol 13:774-783

Vogel S (1994) Life in moving fluids: the physical biology of flow, 2nd edn. Princeton University Press, Princeton, NJ

Wilcove DS (1985) Nest predation in forest tracts and the decline of migratory songbirds. Ecology 66:1211-1214

Worthington DG, Ferrell DJ, McNiell SE, Bell, JD (1992) Effects of the shoot density of seagrass on fish and decapods: are correlations evident over larger spatial scales? Mar Biol 112:139-146

Zar JH (1984) Biostatistical analysis. Prentice Hall, Englewood Cliffs, NJ

Submitted: November 3, 2001; Accepted: March 25, 2002 Proofs received from author(s): October 28, 2002 